of a plate, gave a track of an $\alpha$-ray of energy $10^{8}$ electron volts. The ion content of the air roughly follows the cosmic ray activity at great heights. Previous records only went up to $30,000 \mathrm{ft}$. In these experiments, the maximum was observed at $61,000 \mathrm{ft}$. of 81 times that at sea-level, and at the greatest height of $72,000 \mathrm{ft}$. this figure fell to 50 . There may be some connexion between this and the observed decrease in the strength of radio signals received on the ground from above a height of $60,000 \mathrm{ft}$. Other results quoted are that 20 per cent of the ozone content of the atmosphere lies below 72,000 ft., the composition of stratosphere air is insignificantly different from that at sea-level and above $60,000 \mathrm{ft}$. only moderate wind velocities ranging up to 42 miles per hour are met with. From the temperature-altitude chart given, it appears that the temperature ranged round about $-70^{\circ} \mathrm{F}$. from $35,000 \mathrm{ft}$. to the maximum heights from 9.40 a.m. to 2 p.m.

\section{The Impact of Science on Social Organisation}

THE twenty-eighth Moncure Conway Memorial lecture was delivered on May 20 by Prof. Lancelot Hogben, who dealt especially with the impact of scientific knowledge on contemporary social organisation. The democracies of Western civilisation, Prof. Hogben said, have reached a crisis with which a social personnel of government trained in a humanism without roots in scientific technology are not equipped to deal. Current political thought is permeated with a body of economic doctrine which includes within its scope no conspectus of emergent technological forces reshaping national policy and international relations. The result is a growing distrust of the powers of education and rational persuasion. In the long run, the stability of Western democracy must depend on whether we can devise an education adapted to the conditions of a society which makes increasing demands on technical knowledge. The necessary reorientation of cultural values and of research in social studies can only be brought about by enlisting to the task a new personnel with naturalistic training and the executive competence which laboratory experience calls forth. The primary business of social inquiry should be devising the social machinery to make available for human welfare the plenty which science offers. The lecture is published by Messrs. Watts and Co., 5 and 6 Johnson's Court, Fleet Street, London, E.C.4 (price 2s. net; by post, $2 s$. 2d.).

\section{Chemistry of Crystals}

THE thirty-fourth Bedson Lecture was delivered at Armstrong College, Newcastle-upon-Tyne, on May 8, by Dr. C. H. Desch, his subject being "The Chemical Properties of Crystals". Dr. Desch said that a solid metal is a crystalline mass of which the chemical, as well as physical properties are anisotropic; acid attack, for example, not being uniform, but producing geometrically shaped pits indicating the symmetry of the constituent crystals. This constitutes a part of the evidence for a secondary or mosaic structure in crystals. The boundaries between the individual crystals have different chemical properties from the mass. Their form corresponds with that of foam cells, being determined by surface tension, and in certain alloys they can be separated by the action of specific reagents. Certain brasses containing aluminium, for example, fall to pieces, the grains separating like sand, when placed for a few seconds in a solution of mercurous nitrate. In the stainless steels, such intercrystalline disruption is explained by the segregation of carbides, but in other instances no boundary constituent has been detected. The stability of iron, aluminium and stainless steel in air is explained by the presence of a surface film of oxygen or oxide. The greatly increased chemical activity of a metallic surface under high local pressures, as in abrasion, was also discussed. The effect known as 'corrosion fatigue' is caused by the combined action of alternating stresses and chemical attack, in which the properties of the film and of minute cracks both play a part. Dr. Desch concluded with an account of the transformations within solid solutions, including the work of Prof. W. L. Bragg on the changes from disorder to order in a lattice.

\section{Lectures to Secondary School Pupils}

WITH the object of bringing young people from secondary schools into contact with some aspects of progressive science and its applications, the British Science Guild arranged last year for two lectures by Mr. C. C. Paterson, director of the research laboratories of the General Electric Company, to pupils from secondary schools for girls in the London area. The lectures were delivered at the Institution of Electrical Engineers, and the subject was "The Electron Liberated: its Industrial Consequences". Sir Albert Howard, the honorary secretary of the Guild, has provided for the continuance of this successful enterprise under the title of the Gabrielle Howard Memorial Lecture; and on Tuesday and Wednesday last, May 26 and 27, Prof. W. L. Bragg delivered this lecture upon the subject of "Telegraphs and Telephones". The lecture on the first day was to boys from London Secondary Schools, and on the second to girls from London Secondary Schools. On both occasions, the lecture was given at the Royal Institution, by kind permission of the Managers. Through the courtesy of Messrs. G. Bell and Sons, the young people who attended the lectures were able to take away with them a pamphlet containing a reprint of the chapter on telegraphs and telephones from Prof. Bragg's book on "Electricity" just published by Messrs. Bell.

\section{Whirlpools and Vortices}

AT the Friday evening discourse at the Royal Institution on May 22, Prof. E. N. da C. Andradel discussed "Whirlpools and Vortices". The best example of what is ordinarily thought of as a vortex is the whirlpool that is formed where the water runs out of a bath or basin. There is a widespread belief that this always spins one way, clockwise or counter-clockwise, and that this is due to the rotation 
of the earth. Actually, however, if the water is allowed to come to complete rest in a vessel where the hole is accurately in the middle, and if the plug is carefully withdrawn, no whirlpool is formed. The whirlpool that is generally observed is due to some slight rotation given to the water near the edge of the vessel, which, by the laws of fluid motion, becomes very much accentuated where the water runs out. The direction of the spin depends on the direction of this slight motion. If the spin is actually always in the same direction in a particular bath, it is because of some chance influence, such as the position of the taps. The spin of the earth should actually give rise to a rotation of the water where it runs out, but the effect is far too small to be observed with a bath or basin. Where a large still sheet of water runs out through a vertical pipe, as at the intake of a water turbine, the effect should, however, be large enough to observe. It is, in fact, found that under these conditions whirlpools form, and that the spin of the water is in an opposite direction in the northern and in the southern hemisphere, as it should be. The consideration of vortices is extremely important for aircraft or other bodies moving through the air, and the whole object of stream-lining is to avoid the formation of vortices, which fritter away energy. The sensitive flame, which ducks in response to sounds, is, it turns out, an example of vortex motion, the vortices being produced as a consequence of the sound vibration.

\section{New Guinea Exhibition}

AN exhibition of ethnographical objects from New Guinea and the islands of the Malay Archipelago under the auspices of the Royal Anthropological Institute opened at 10 Grosvenor Square, London, S.W., on May 26, and will remain open for three or four weeks. The specimens were collected by Lord Moyne during a cruise on his yacht Rosaura between November and February last, and with them is a remarkable series of photographs taken at the same time by Lady Broughton. The section of the exhibition which will afford the greatest interest is that illustrating the culture of the newly discovered Aiome, a light-skinned pygmy race inhabiting the hills near the Middle Ramu River in the mandated territory of New Guinea, who had not previously had any contact with white civilisation. Their skin is only slightly darker than that of a well-sunburned European, and their hair a very dark brown. The average height is $4 \mathrm{ft} .6 \frac{1}{2}$ in., male, and $4 \mathrm{ft}$. 2 in., female. They are surrounded by dark-skinned tribes of normal stature and the general New Guinea type. Their appearance is well illustrated in a number of photographs, which show the mode of wearing the articles of adornment included in the collection, such as bands made up of stems of Dendrobium and threaded grass seeds, and tree-bark head-dresses. A collection of skulls comes from a deserted village, in which they were stored in bundles outside or inside the houses. This collection includes two very distinct types of head, one large and one small. The former is distinctly Australoid in appearance, with prominent brow ridges and receding forehead. It is remarkable as coming from New Guinea. No explanation of the abandonment of the village was obtained, though it was found to be full of the possessions of its former inhabitants, including a number of objects of the greatest cultural interest, among them drums, carved shields and curious head-dresses of possibly ritual purpose.

\section{Homer's Troy}

A THIRD, and possibly final, stage in the archæological exploration of Troy has been reached with the excavations organised by the University of Cincinnati under the field direction of Dr. Carl Bleger, formerly assistant director of the American School of Archæology at Athens. It is remarkable that of the three great sites of Homeric civilisation, Troy, Mycenæ and Tiryns, the first-named, which inspired the excavation of the archæological sites of the eastern Mediterranean, should still, at the last, afford a problem in the exact determination of its chronological and cultural relations. Schliemann's final identification of the Sixth City at Hissarlik, and not the Second, as the Homeric Troy in 1890, and Dorpfeld's demonstration of a sequence of nine phases in the history of the city, extending from the Early Bronze Age to Roman times four years later, satisfied a generation which knew not Knossos and the history of Helladic culture. It has since become evident that the Sixth City, notwithstanding $\mathbf{M y}$ cenæan contacts, is neither completely contemporary with, nor its culture identical with that of, the Mycenæan age. The work of the American expedition, as is indicated by Mr. E. J. Forsdyke in his lucid summary of the present position of the archæological and historical problem in The Times of May 22, has confirmed this by showing that the Sixth City goes back to Pre-Mycenæan Middle Helladic, and that "the Achæan moment", the period when the Achæan military aristocracy held sway, fortified by matrimonial alliances with Mycenæan heiresses, which corresponds with the conditions of the Homeric world, is represented by an inferior reconstruction after the Sixth City had been destroyed by earthquake about 1300 B.c., in which the walls were repaired in rougher masonry and the houses irregularly built with odd stones from the ruins. About 1200 B.c. this Seventh City was destroyed by fire. It was rebuilt and inhabited, presumably, by the Achæan conquerors.

\section{Co-ordination of Research}

The Research Co-ordination Committee, which was formed a few months ago as the result of an informal meeting of persons connected with organisations interested in the application of science to present-day problems (see NATURE, February 22, p. 311), reported on its activities at a meeting on May 23 to the group from which it arose. The Committee, after making a preliminary list of problems which need co-ordination, decided to consider one or two in detail and to work out a technique of co-ordination that could be generally 